\title{
PENGABDIAN KEPADA MASYARAKAT MELALUI BUDIKDAMBER UPAYA PEMENUHAN GIZI IKAN DIMASA PANDEMI COVID-19 DI KELURAHAN TAMAN BARU KECAMATAN BANYUWANGI
}

\author{
Nadya Adharani*), Sulistiono, Nandya Fitri Rachmawati
}

\author{
Program Studi Teknologi Hasil Perikanan \\ Fakultas Pertanian, Universitas PGRI Banyuwangi \\ Jalan Ikan Tongkol No. 1, Kertosari, Banyuwangi 68416. Telp. (0333) 4466937 \\ *e-mail: nadya.adharani@gmail.com
}

\begin{abstract}
Abstrak
Bulan Maret 2020 Indonesia dilanda wabah penyakit membahayakan yakni adanya virus corona disease atau yang sering disebut pandemic covid-19. Meningkatnya masyarakat Indonesia yang terkonfirmasi positif corona menyebabkan pemberlakukan social distancing sangat ketat di seluruh wilayah atau yang dikenal dengan peraturan PSBB. Tentu pandemic Covid-19 berdampak buruk disemua sektor, terutama pada sektor ekonomi dan pangan. Salah satu daerah yang berdampak dari pandemic Covid-19 adalah Desa Tamanbaru Kecamatan Banyuwangi, sebagai langkah awal untuk penguatan ekonomi dan pangan di Desa Tamanbaru Banyuwangi maka dilakukan pelatihan dan penyuluhan dalam kegiatan pengabdian kepada masyarakat Program Studi Teknologi Hasil Perikanan UNIBA melalui program Budikdamber (Budidaya Ikan dan Tanaman Dalam Ember), budikdamber merupakan perpaduan teknik pertanian dan perikanan yang membutuhkan modal cukup murah dan mudah. Komoditas ikan yang di budidaya adalah ikan lele dan menggunakan tanaman kangkung. Kelompok masyarakat di Desa Tamanbaru Kabupaten Banyuwangi telah berhasil dengan program budikdamber sehingga mampu menciptakan peluang usaha dan mempertahankan gizi pangan ditengah masa pandemic Covid-19.
\end{abstract}

Kata kunci: Budikdamber, Gizi Ikan, Covid-19, Banyuwangi

\begin{abstract}
In March 2020 Indonesia was hit by an outbreak of a dangerous disease, namely the presence of coronavirus disease or commonly called pandemic covid-19. The increasing number of Indonesians who are confirmed positive corona causes the implementation of social distancing is very strict throughout the region or known as PSBB regulations. Of course, the Covid 19 pandemic has an adverse impact on all sectors, especially in the economic and food sectors, one of the areas affected by the Covid 19 pandemic is Tamanbaru Village, Banyuwangi Sub-District, as a first step to strengthen the economy and food in Tamanbaru Banyuwangi Village, so that training and counseling is carried out in community service activities uniba Fishery Technology Study Program through the Budikdamber (Fish and Plant Cultivation in Bucket) program. Budikdamber is a combination of agricultural and fishery techniques that require capital is quite cheap and easy. Fish commodities that are cultivated are catfish and use kale plants. Community groups in Tamanbaru Village, Banyuwangi Regency have succeeded with budikdamber program so as to create business opportunities and maintain food nutrition in the midst of the covid 19 pandemic.
\end{abstract}

Keywords: Budikdamber, Nutrition of Fish, Covid-19, Banyuwangi 


\section{PENDAHULUAN}

Pertengahan bulan Maret, Indonesia dilanda musibah melalui penyebaran virus Coronavirus disease (Covid-19) yang mengancam segala aspek terutama kesehatan manusia. WHO mendeklarasikan Covid-19 sebagai darurat kesehatan pada akhir Januari 2020 sehingga banyak negara-negara yang membuat berbagai kebijakan seperti social distanding termasuk di Indonesia. Semenjak penyebaran Covid-19 terjadi mengakibatkan seluruh kegiatan seharihari terbatas, hingga dianjurkan bekerja dari rumah atau dilakukan secara dalam jaringan atau biasa disebut daring.

Salah satu wilayah yang terkena dampak pandemic Covid-19 adalah Kabupaten Banyuwangi, memasuki awal September 2020, Banyuwangi memasuki zona merah dan beberapa kebijakan terkait social distansing di berlakukan oleh pemerintah kabupaten Banyuwangi sehingga menyebabkan penutupan di beberapa tempat seperti sekolah, pusat pembelanjaan, taman wisata kuliner, sarana olahraga, dan lain-lain. Kecamatan Banyuwangi merupakan daerah 'Kota” yang ramai atau pusat di Banyuwangi, semenjak pandemic terjadi kondisi menjadi berubah, beberapa tempat diterapkan penutupan serta semua kegiatan di tunda seperti festival yang tiap tahunnya dilakukan oleh Banyuwangi. Selain itu, dampak buruk yang dirasakan masyarakat Banyuwangi adalah pemutusan kontrak kerja atau PHK pegawai kontrak, disusul dengan ketahanan pangan masyarakat yang terancam karena kesulitan membeli bahan pangan.

Kebutuhan pokok (pangan) seharihari masyarakat harus dipenuhi ditengah pandemic. Oleh karena itu, dibutuhkan usaha untuk mencukupi kebutuhan hidup. Salah satunya adalah budidaya ikan dan tanaman dengan pemanfaataan lahan pekarangan rumah serta penggunaan biaya yang murah dan tentu mudah dalam aplikasinya dapat melalui kegiatan budikdamber (budidaya ikan dan tanaman dalam ember). Budikdamber dengan sistem akuaponik berasal dari kata "akuaponik" yang artinya budidaya ikan dan "hidroponik" yang artinya wadah budidaya berupa bak atau ember, dua kata tersebut menjadi gagasan kegiatan budidaya melalui sistem budikdamber. Budikdamber merupakan solusi pangan masa depan yang dimana seluruh masyarakat dapat melakukannya karena kemudahan dalam menjalaninya. Cukup dengan lahan yang sempit serta alat dan bahan yang mudah didapatkan sehingga mudah dikembangkan.

Melalui program budikdamber, masyarakat tidak perlu khawatir dalam 
pemenuhan gizi untuk kebutuhan protein hewani dan sayuran bagi keluarga. Terlebih saat ini Pemerintah menegaskan masyarakat untuk menerapkan new normal atau dimana masyarakat diizinkan untuk melakukan aktivitas seperti biasa. Namun dengan tetap mematuhi protokol kesehatan yang berlaku dan masyarakat dituntut untuk tetap produktif di era new normal. Pengabdian kepada masyarakat yang dilakukan tim dosen dari Program Studi Teknologi Hasil Perikanan adalah pelatihan dan penyuluhan program budikdamber sebagai upaya ketahanan pangan dalam rangka pemenuhan gizi dimasa pandemic Covid-19, pelaksanaan dilakukan di Kelurahan Tamanbaru Kacamatan Banyuwangi.

Budikdamber mengadaptasi Teknik Yumina Bumina yang merupakan teknik budidaya yang memadukan antara ikan dan sayuran serta buah-buahan. Pada budidaya Yumina-Bumina dikenal empat sistem, yaitu: rakit, aliran atas, aliran bawah serta pasang surut. Pada sistem aliran atas ini pergerakkan air melalui atas ke setiap wadah media tanam sehingga nutrisi yang berasal dari limbah budidaya dapat tersebar merata ke setiap batang tanaman. Agar melancarkan sistem sirkulasi yang berputar, sering kali dibantu dengan alat pompa air, dan beberapa bahan seperti tempat media tanaman tanaman, wadah atau bak ikan, saluran air, batu apung, komoditas ikan (seperti lele, nila, mas, mujair), tanaman (seperti kangkung, pakcoy, bayam, tomat, terong ungu) (Supendi et al., 2015).

Model akuaponik mini ini mengintegrasikan budidaya ikan dan sayuran sekaligus pada lahan yang terbatas, dan kebutuhan lauk yang tergolong mudah dan murah. Tentu lebih menguntungkan dibandingkan dengan teknik budidaya secara kovensional (Saputri et al., 2020). Budidaya sistem akuaponik pada prinsipnya menghemat penggunaan lahan dan meningkatkan efisiensi pemanfaatan hara dari sisa pakan dan metabolisme ikan, sehingga menciptakan budidaya yang ramah lingkungan (Susetya et al., 2020). Melalui perancangan sistem budidaya ikan menggunakan media atau wadah yang kecil (dalam ember 60 liter) diharapkan menjadi salah satu solusi masalah terkait terbatasnya lahan budidaya ikan dan membantu mencukupi kebutuhan protein hewani masyarakat di era new normal.

\section{METODE PENELITIAN}

\section{Waktu dan Tempat}

Kegiatan PKM pada hari Sabtu, 20 Juni 2020 dan dirancang di Program Studi Teknologi Hasil Perikanan, Fakultas Pertanian, Universitas PGRI Banyuwangi. Mitra dalam kegiatan ini adalah kelompok 
masyarakat di Kelurahan Tamanbaru, Kecamatan Banyuwangi.

\section{Alat dan Bahan}

Peralatan yang digunakan dalam kegiatan PKM ini adalah ember ukuran 60 L, gelas plastik bekas, kawat lentur, tang, solder, pakan ikan, keran, aerator, selang, pemberat selang.

Bahan-bahan yang digunakan diantaranya benih lele ukuran 7-8 cm, benih kangkung, arang batok kelapa, tisu.

\section{Pengumpulan Data}

Data yang diambil dari kegiatan PKM ini adalah wawancara kepada peserta yang mengikuti kegiatan PKM.

\section{Langkah Kerja Pembuatan Budikdamber}

Adapun langkah kerja yang dilakukan diantaranya sebagai berikut:

1. Siapkan gelas plastik sebagai wadah bibit sayuran, lubangi bagian bawah gelas menggunakan benda tajam atau solder.

2. Masukkan arang batok kelapa yang telah dihancurkan halus ke dalam gelas plastik sebanyak 3/4 dari ukuran gelas. Selanjutnya masukkan benih kangkung di atas arang kemudian tutup menggunakan tisu. Jika yang dimasukkan adalah bibit kangkung yang telah disemai maka masukkan beserta akarnya. Selanjutnya tutup kembali dengan arang sebanyak 50$70 \%$ ukuran gelas.
3. Kaitkan gelas plastik dengan ember menggunakan kawat berukuran 7-12 cm yang telah dibentuk.

4. Isi ember dengan air sebanyak 60 liter atau sesuai dengan ukuran ember.

5. Isi ember dengan bibit ikan lele ukuran 7-8 atau 10-12 cm (semakin besar semakin baik). Banyaknya benih lele yang ditebar sesuai dengan besarnya volume air, selanjutnya adalah rangkai gelas dalam ember.

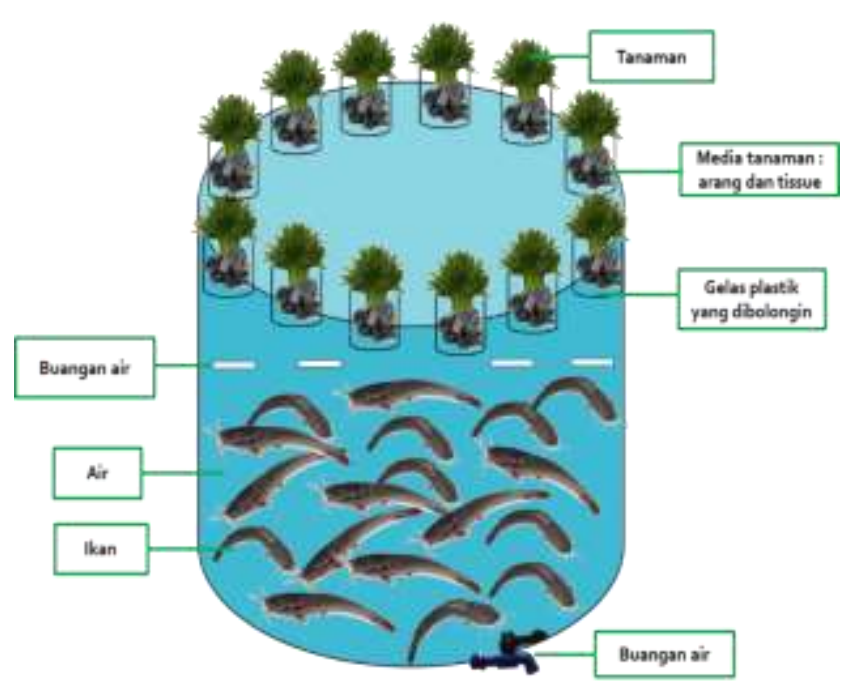

Gambar 1. Ilustrasi Budikdamber Sumber : Pribadi

\section{HASIL DAN PEMBAHASAN}

\section{Sosialisasi}

Kegiatan sosialisasi dilakukan di Kawasan Masjid Darul Arqom Tamanbaru Banyuwangi yang dipimpin oleh ketua takmir yakni Bapak H. Ahmad Pirnada dan kegiatan pengabdian berlangsung selama 2.5 jam terhitung dari jam 08.30-11.00 WIB. Sosialisasi menghadirkan sekitar 25 masyarakat yang dibentuk menjadi 6 
kelompok. Pembentukan kelompok untuk mempermudah pelatihan sekaligus sebagai dasar usaha budidaya ikan skala rumah tangga. Selama pelaksanaan berlangsung seluruh masyarakat yang hadir menggunakan masker. Beberapa titik telah disediakan tempat cuci tangan dan handsanitizer, serta semua yang hadir tetap melaksanakan kegiatan dengan protokol kesehatan.

Pada tahapan kegiatan, berawal dari diskusi dengan kelompok masyarakat setempat dengan tujuan, antara lain:

1. Menganalisis masalah yang timbul selama Covid-19 terutama pada faktor ketahanan pangan agar pemenuhan gizi sehari-hari terpenuhi.

2. Melakukan diskusi terkait pemanfaatan lahan yang sempit dalam hal ini adalah pekarangan rumah sebagai wadah wirausaha budidaya ikan dan tanaman.

\section{Pelatihan atau Ceramah}

Pada bagian pelatihan, tim PKM mempersiapkan materi dan bahan serta alat kepada masyarakat. Materi yang disampaikan adalah:

1. Keunggulan budidaya ikan dalam ember dalam sistem akuaponik jika dibandingkan dengan sistem budidaya lainnya.

2. Pelatihan yang diawali dengan kebutuhan alat dan bahan hingga sampai tahap akhir pada proses pemanenan ikan dan sayuran.

3. Manajemen kualitas air selama proses budikdamber berlangsung.

4. Manajemen wirausaha pada proses Budikdamber secara berkelanjutan.

\section{Praktek Lapangan}

Dalam praktek lapangan pelatihan budidaya ikan dalam ember (Budikdamber) terdapat beberapa tahapan yang dilakukan diantaranya sebagai berikut:

1. Tahap persiapan alat dan bahan budidaya

2. Tahap persiapan benih ikan

3. Tahap pembuatan wadah budidaya ikan dan tanaman kangkung

4. Tahap pengontrolan budidaya ikan dalam ember

5. Tahap manajemen

6. Tahap pemasaran ikan

Berikut adalah tahapan dalam pelaksanaan pelatihannya:

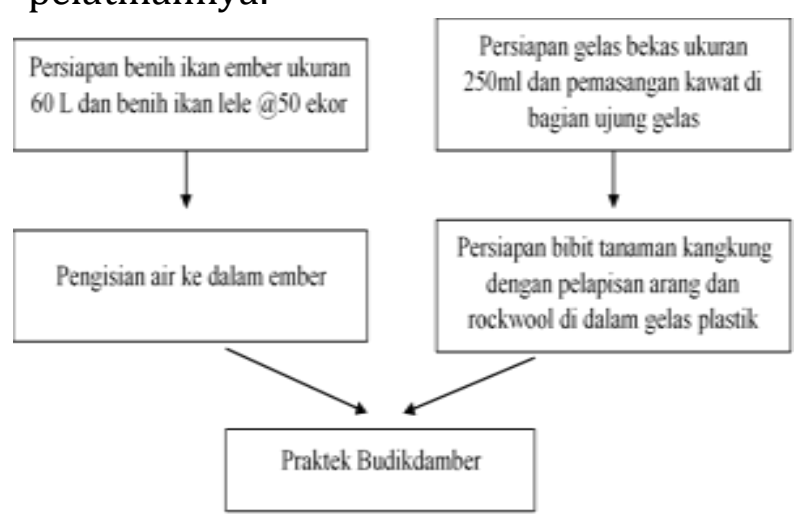

Gambar 2. Tahapan Kegiatan 


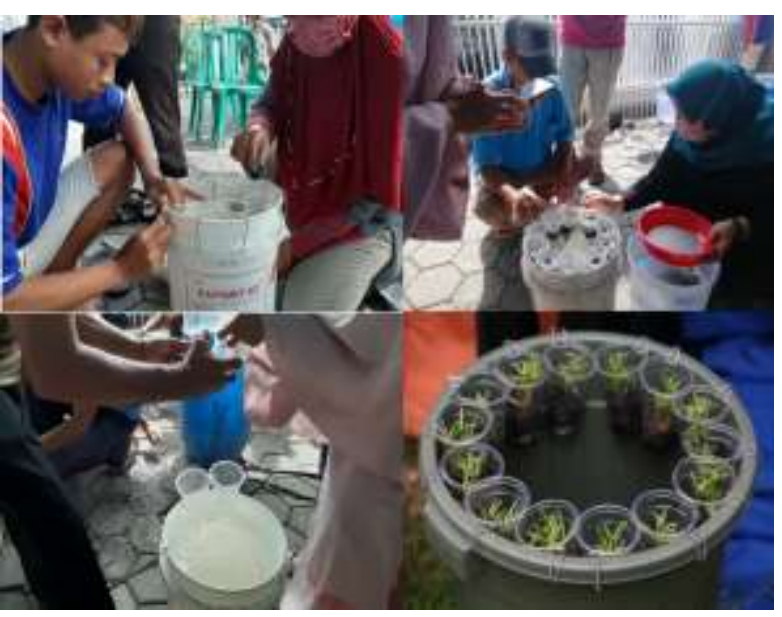

Gambar 3. Dokumentasi Kegiatan

Hal-hal yang perlu diperhatikan dalam pelaksanaan Budikdamber:

1. Selama proses berlangsung, ember ditaruh di bawah sinar matahari

2. Pemberian pakan dilakukan sebanyak dua kali (pagi dan sore).

3. Jika terjadi bau busuk yang disebabkan amonia, maka ikan akan mengalami penurunan nafsu makan, ikan menggantung (kepala di atas dan ekor di bawah), segera lakukan penggantian air sebanyak 3/4 dari volume ember, atau dapat juga degan cara penyedotan kotoran yang berada di dasar ember meggunakan selang atau biasa disebut dengan penyiponan air.

4. Tanaman kangkung akan terlihat tumbuh di hari ke-3. Jika timbul daun yang menguning selama proses pertumbuhan maka segera buang bagian daun atau batang yang menguning.
5. Penampakan air akan berubah menjadi warna hijau. Saat pemberian pakan, saat itu pula tanaman kangkung perlu dilakukan penyiraman. Maka diberikan saat pagi dan sore hari. Penyiraman kangkung menggunakan air yang berasal dari ember.

6. Pergantian air dilakukan 10-14 hari sekali. Jika ingin melakukan sifon air maka penyedotan sebanyak 5-8 liter, bisa lebih atau $3 / 4$ dari volume air keseluruhan, ganti dengan air bersih. Jika kangkung membesar maka dibutuhkan air lebih banyak, tambahkan air setinggi leher ember. Hal ini dilakukan agar air menyentuh akar kangkung.

7. Panen tanaman kangkung pertama adalah 14-21 hari sejak tanam. Saat panen sisakan kembali bagian bawah atau tunas kangkung untuk pertumbuhan kembali. Panen ke-2 dan selanjutnya berjarak 10-14 hari sekali. Panen kangkung bisa bertahan 4 bulan.

8. Panen ikan lele dalam 2-2.5 bulan, perlu diketahui tingkat bertahan hidup (survival rate) ikan lele 40-100\%. Ketika panen ikan, gunakan serokan hingga ke dasar ember secara cepat untuk menghindari ikan akan meloncat ke atas.

\section{Tahap Pemanenan}


Tahap panen kangkung pertama sekitar 14-21 hari sejak tanam. Sisakan bagian bawah atau tunas kangkung untuk pertumbuhan kembali, panen kedua dan selanjutnya berjarak 10-14 hari sekali. Volume panen sayuran (kangkung) akan berkurang ketika sudah memasuki bulan ke tiga dan ke empat pemeliharaan. Ketika jumlah panen sudah mulai berkurang bisa dilakukan kembali penanaman kembali melalui pergantian kangkung dengan bibit baru. Ikan lele dapat dipanen jika telah dilakukan budidaya selama 1.5-2 bulan. Panen lele tidak dilakukan secara serentak untuk seluruh ember, karena besar ikan lele tidak seragam untuk pemeliharaan selama dua bulan tersebut.

\section{KESIMPULAN}

Kegiatan pengabdian kepada masyarakat yang diselenggarakan di Kelurahan Tamanbaru, Kecamatan Banyuwangi dapat meningkatkan pengetahuan dan keterampilan masyarakat untuk tetap produktif dalam kehidupan sehari-hari ditengah pandemic Covid-19. Di sisi lain adanya peningkatan kemandirian bagi masyarakat yang hanya memanfaatkan lahan perkarangan yang tidak terlalu luas melalui teknik budikdamber.

\section{DAFTAR PUSTAKA}

Febri, S.P., Alham, F., Afriani, A. 2019. Pelatihan BUDIKDAMBER (Budidaya Ikan Dalam Ember) Di Desa Tanah Terban Kecamatan Karang Baru.

Saputri., Sherina A.D., Dessy R. 2020. Budidaya Ikan Dalam Ember: Strategi Keluarga Dalam Rangka Mempertahankan Ketahanan Pangan Ditengah Pandemi Covid-19. Jurnal Ilmu Perikanan Tirtayasa. Vol. 2(1): 103.

Supendi., Maulana, M.R., Fajar, S. 2015. Teknik Budidaya Yumina sistem Aliran Atas di Bak Terpal. Buletin Teknik Literatur Akuakultur. Vol. 13(1): 101106.

Susetya., I.E., Zulham A.H. 2020. Aplikasi Budikdamber (Budidaya Ikan Dalam Ember) Untuk keterbatasan Lahan Budidaya Di Kota Medan. ADIMAS TALENTA. Vol. 3(2): 416-420 